\title{
MCKENZIE NECK EXERCISE DAN FORWARD HEAD POSTURE EXERCISE DAPAT MENURUNKAN NYERI LEHER MEKANIK PADA PENGGUNA SMARTPHONE
}

\author{
Arisandy Achmad ${ }^{1}$, I Made Jawi ${ }^{2}$, Sugijanto ${ }^{3}$, Luh Putu Ratna $S^{4}$, Ida Sri Iswari ${ }^{5}$, \\ I Putu Adiartha $\mathbf{G}^{6}$ \\ ${ }^{1}$ Program Studi Magister Fisiologi Keolahragaan Universitas Udayana, Denpasar \\ ${ }^{2}$ Departemen Biomedik Universitas Udayana, Denpasar \\ ${ }^{3}$ Fakultas Fisioterapi Universitas Esa Unggul, Jakarta \\ ${ }^{4}$ Departemen Fisiologi Keolahragaan Universitas Udayana, Denpasar \\ ${ }^{5}$ Departemen KSM Mikrobiologi Klinik RSUP Sanglah, Denpasar \\ ${ }^{6}$ Departemen IKK/IKP Universitas Udayana, Denpasar
}

E-Mail: fisioandyy@gmail.com

\begin{abstract}
ABSTRAK
Pendahuluan: Nyeri leher mekanik merupakan masalah besar yang sering dikeluhkan oleh pengguna smartphone. Penyebab utamanya karena faktor posisi forward head posture sewaktu melihat ke arah layar smartphone. Posisi ini tidak saja membuat perubahan kurva servikal menjadi lebih datar, juga dapat memberikan beban berlebih pada otot, ligamen, sendi, dan tulang pada leher di bagian posterior, serta otot punggung atas dan bahu, sebagai akumulasi pencetus nyeri leher mekanik. Tujuan: Tujuan penelitian ini adalah untuk membuktikan bahwa program McKenzie Neck Exercise dan Forward Head Posture Exercise sama-sama efektif dalam menurunkan nyeri leher mekanik pada pengguna smartphone dan tidak ada perbedaan efektivitas antara kedua teknik tersebut. Metode: Penelitian ini adalah penelitian eksperimental pretest and posttest comparison group design. Sebanyak 22 orang subjek penelitian, berusia 22-28 tahun, mengalami nyeri leher mekanik nonspesifik kronik, dan tidak pernah mengalami spondylolisthesis, cedera, fraktur dan hernia nucleus pulposus pada area leher, direkrut untuk mengikuti penelitian ini. Subjek penelitian dibagi menjadi 2 Kelompok. Kelompok I diberikan program McKenzie Neck Exercise dan Kelompok II diberikan program Forward Head Posture Exercise dengan durasi latihan yang sama, yaitu 30 menit per hari selama 1 pekan. Alat ukur yang digunakan untuk mengevaluasi perubahan nyeri mekanik leher adalah Northwick Neck Pain Tool. Analisis statistik menggunakan uji Wilcoxon untuk membandingkan hasil prestest dan posttest tiap Kelompok, dan uji Mann-Whitney untuk membandingkan perubahan nyeri antara kedua Kelompok. Hasil: Hasil penelitian ini menunjukkan bahwa terdapat penurunan nyeri leher yang signifikan $(p<0,05)$ baik pada Kelompok I maupun Kelompok II $(3,36 \pm 0,50-1,18 \pm 0,40$ vs. 3,36 $\pm 0,50-1,36 \pm 0,50)$. Hasil perbandingan penurunan nyeri menunjukkan bahwa tidak ada perbedaan yang signifikan $(p 0,44)$ antara

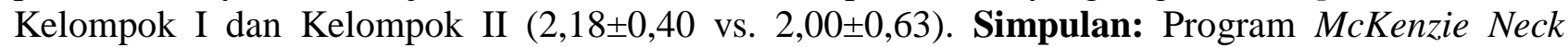
Exercise dan Forward Head Posture Exercise efektif dalam menurunkan nyeri leher mekanik pada pengguna smartphone dengan efektivitas yang sama baiknya antara ke dua teknik tersebut.
\end{abstract}

Kata Kunci: Nyeri leher mekanik, pengguna smartphone, McKenzie Neck Exercise dan Forward Head Posture Exercise. 


\title{
MCKENZIE NECK EXERCISE AND FORWARD HEAD POSTURE EXERCISE CAN REDUCE MECHANICAL NECK PAIN IN SMARTPHONE USERS
}

\author{
Arisandy Achmad ${ }^{1}$, I Made Jawi ${ }^{2}$, Sugijanto ${ }^{3}$, Luh Putu Ratna S $^{4}$, Ida Sri Iswari ${ }^{5}$, \\ I Putu Adiartha $\mathbf{G}^{6}$
}

\begin{abstract}
Introduction: Mechanical neck pain is a major problem that often complained by smartphone users. It caused by forward head posture position when looking at the smartphone screen. This position not only makes the cervical curve being flatter, it can be overuse on muscles, ligaments, joints, and bones around the neck, especially the posterior neck, the upper back and shoulder, as triggers accumulation of mechanical neck pain. Objective: The purpose of this study was to prove that the McKenzie Neck Exercise and Forward Head Posture Exercise programs are equally effective in reducing mechanical neck pain in smartphone users and there is no difference in effectiveness rate between this two techniques. Method: This is an experimental study using pretest and posttest comparison group design. Total of 22 study subjects, aged 22-28 years, suffered from chronic nonspecific mechanical neck pain, and never had experienced spondylolisthesis, injuries, fractures and hernia nucleus pulposus in the neck area, were recruited to participate in this study. The research subjects were divided into 2 groups. Group 1 was given the McKenzie Neck Exercise program and group 2 was given the Forward Head Posture Exercise program with same duration, 30 minutes per day for 1 week. The measuring instrument that been used to evaluate changes of mechanical neck pain is Northwick Neck Pain Tool. Wilcoxon test was used to compare the results of prestest and posttest of each group, and Mann-Whitney test was used to compare changes of pain between the two groups. Results: The results of this study showed that there was a significant decrease in neck pain $(p<0.05)$ in both groups $(3.36 \pm 0.50-1.18 \pm 0.40$ vs. $3.36 \pm 0.50-1.36 \pm 0.50)$. The comparison result of pain reduction showed that there was no significant difference $(p 0.44)$

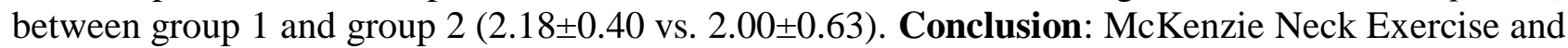
Forward Head Posture Exercise programs are effective to reduce mechanical neck pain in smartphone users with no difference of effectiveness between the both of this techniques.
\end{abstract}

Keywords: Mechanical neck pain, smartphone users, McKenzie Neck Exercise and Forward Head Posture Exercise.

\section{PENDAHULUAN}

Nyeri leher mekanik erat dikaitkan dengan faktor posisi forward head posture pada usia dewasa tua. Seiring perkembangan teknologi memasuki era telepon pintar atau smartphone, nyeri leher mekanik justru menjadi sebuah keluhan yang lazim ditemukan pada usia remaja dan dewasa muda, semakin tinggi, semakin banyak. Penyebabnya adalah mayoritas pengguna smartphone melihat ke layar smartphone dalam posisi forward head posture. Bahkan sering dalam durasi lama ${ }^{1,2}$.

Lima tahun terakhir, banyak peneliti mengangkat permasalahan ini sebagai epidemik serius di seluruh belahan dunia, dengan estimasi antara $66 \%$ hingga $90 \%$ dari pengguna smartphone mengeluhkan nyeri leher mekanik selama mengakses smartphone mereka dalam posisi forward head posture ${ }^{3}$. Peneliti lainnya 
menggambarkan bahwa kurva normal servikal menjadi lebih datar dan terbebani karena mempertahankan posisi forward head posture, yang dapat mengakibatkan kerja berlebih pada otot, ligamen, sendi, serta tulang pada leher

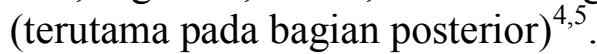

Sebuah penelitian melaporkan bahwa dari 1049 orang di Australia yang menggunakan smartphone dalam posisi forward head posture, $70 \%$ dewasa muda dan 30\% remaja mengeluhkan nyeri leher mekanik, terutama ditemukan pada usia 18-30 tahun ${ }^{6}$. Nyeri leher mekanik sendiri memperlihatkan adanya gejala rasa sakit disertai rasa tegang pada bagian belakang kepala, leher, punggung atas, dan bahu, bersifat kronik non spesifik ${ }^{7,8}$.

Salah satu studi dari systemic review and meta-analysis berpendapat bahwa metode corrective neck exercise dapat mengatasi nyeri leher mekanik sekaligus mengoreksi kurva dan meningkatkan kestabilan servikalis, terutama mereka yang banyak bekerja dalam posisi forward head posture ${ }^{9}$.

Pemilihan program McKenzie Neck Exercise dan Forward Head Posture Exercise sebagai bentuk corrective neck exercise, tentu saja dapat menjadi solusi alternatif dan jalan keluar dalam mengatasi nyeri leher mekanik pada pengguna smartphone, dengan jalan mengaktivasi mechanoreceptor serabut saraf bermyelin tebal tipe $A \beta$ terutama ruffini (tipe II) dan intertisial (tipe IIIa) yang terletak di kulit, connective tissue, otot, tendon, serta sendi, untuk menginhibisi serabut saraf bermyelin tipis tipe $\mathrm{C}$ di lamina II, III, dan V substansi gelatinosa (SG). Di samping ke dua program latihan merangsang pelepasan neurotransmitter ensepalin di tingkat spinal dan supraspinal untuk menginhibisi pelepasan neurotransmitter nyeri, seperti histamin, serotonin, bradikinin, asam amino eksitaroris (EAAs) glutamat dan aspartat, calcitonin gene related peptide (CGRP) dan substansi $\mathrm{P}^{10,11}$.

Program McKenzie Neck Exercise dan Forward Head Posture Exercise juga dapat mengaktivasi muscle spindle (MS) dan golgi tendon organ (GTO) untuk mencegah terjadinya penguluran berlebih pada otot antagonis dan merileksasikan otot agonis ${ }^{12}$.
Sehingga nyeri mekanik pada pengguna smartphone menjadi berkurang.

Keunikan dari program McKenzie Neck Exercise dan Forward Head Posture Exercise terletak pada gerakan yang selalu dimulai dari arah sisi nyeri ke arah sisi tidak nyeri, disertai koreksi postur $^{13,14}$. Melalui dua program latihan (McKenzie Neck Exercise dan Forward Head Posture Exercise) ini, sebuah pengetahuan baru tentang cara mengatasi nyeri leher mekanik pada pengguna smartphone, yang efektif, aman, mudah, bisa dilakukan dimana saja, dan kapan saja.

\section{METODE PENELITIAN}

Penelitian ini menggunakan metode true experimental, dengan rancangan pretestposttest comparison group design. Penelitian dilakukan di poliklinik Fisioterapi RSBIA INA'U Kotamadya Makassar dari bulan Februari sampai April 2019. Melibatkan 22 responden yang dibagi ke dalam dua Kelompok (masing-masing 11 responden).

Kelompok I memperoleh program McKenzie Neck Exercise, terdiri atas lima tahapan latihan meliputi; (1) head retraction, (2) neck extension, (3) neck side bending, (4) neck rotation, dan (5) neck flexion. Program latihan ini ditujukan untuk menurunkan nyeri leher mekanik dan memungkinkan restorasi normal fungsi servikalis, untuk memperoleh kembali mobilitas penuh dari vertebra servikalis.

Kelompok II memperoleh program Forward Head Posture Exercise, juga terdiri atas lima tahapan latihan meliputi; (1) massage sternocleidomastoid, (2) neck flexion, (3) chin tucks exercise, (4) shoulder blade squeeze, dan (5) mid sclene and upper trapezius stretch. Program latihan ini lebih ditujukan untuk merileksasikan otot-otot servikalis yang cenderung mengalami over aktif selama melakukan posisi forward head posture, di samping mengoreksi kurva servikalis dan mengurangi nyeri leher mekanik.

Tiap Kelompok diberikan program latihan dengan durasi 30 menit perhari selama sepekan. Responden yang terlibat dalam penelitian ini merupakan pengguna smartphone berusia 23 
hingga 28 tahun, pria dan wanita, terdiagnosis nyeri leher mekanik kronik non-spesifik, disertai gejala rasa sakit dan tegang pada bagian belakang kepala, leher, punggung atas, yang berlangsung selama 1 jam lebih per hari, tanpa riwayat spondilolistesis, cedera, fraktur, dan HNP, pada servikalis.

Untuk mengevaluasi intensitas nyeri, digunakan alat ukur modifikasi Northwick Neck Pain Tool (nilai $1=$ tidak nyeri dan terasa normal sepanjang hari, $2=$ nyeri ringan dan berlangsung kurang dari 1 jam/hari, 3= nyeri sedang dan berlangsung selama 1-4 jam/hari, $4=$ nyeri agak berat dan berlangsung lebih dari $4 \mathrm{jam} / \mathrm{hari}, 5=$ nyeri sangat berat dan berlangsung sepanjang hari).

\section{HASIL PENELITIAN}

\section{Karakteristik Subjek Penelitian}

Tabel 1.

Data Karakteristik Subjek Penelitian

\begin{tabular}{|c|c|c|c|c|}
\hline \multirow{2}{*}{ Variabel } & \multicolumn{2}{|c|}{ KP I } & \multicolumn{2}{|c|}{ KP II } \\
\hline & $\mathbf{f}$ & $\%$ & & $\%$ \\
\hline \multicolumn{5}{|l|}{ Jenis kelamin } \\
\hline Pria & 5 & 45,5 & 5 & 45,5 \\
\hline Wanita & 6 & 54,5 & 6 & 45,5 \\
\hline \multicolumn{5}{|l|}{ Usia (tahun) } \\
\hline Mean \pm SD & 24,8 & $2 \pm 1,94$ & 24 & $18 \pm 1,07$ \\
\hline
\end{tabular}

Tabel 1 di atas memperlihatkan sebuah gambaran karakteristik responden penelitian dengan jumlah wanita lebih banyak daripada pria pada masing-masing Kelompok. Berdasarkan usia berada pada rentang rata-rata 24,82 $\pm 1,94$ tahun untuk Kelompok I dan 24,18 $\pm 1,07$ tahun untuk Kelompok II.

\section{Data Deskripsi Nyeri Leher Mekanik}

Tabel 2.

Data Deskripsi Hasil Pengukuran Nyeri

\begin{tabular}{|c|c|c|c|c|c|c|}
\hline & \multicolumn{3}{|c|}{$\underset{(\mathbf{n}=\mathbf{1 1})}{\mathbf{K P} \mathbf{I}}$} & \multicolumn{3}{|c|}{$\begin{array}{c}\text { KP II } \\
(n=11)\end{array}$} \\
\hline & Min & Max & Mean \pm SD & Min & Max & Mean \pm SD \\
\hline \multicolumn{7}{|c|}{ Nilai nyeri } \\
\hline Pre & 3 & 4 & $3,36 \pm 0,50$ & 3 & 4 & $3,36 \pm 0,50$ \\
\hline Post & 1 & 2 & $1,18 \pm 0,40$ & 1 & 2 & $1,36 \pm 0,50$ \\
\hline
\end{tabular}

Tabel 2 di atas menunjukkan bahwa pada Kelompok I rentang nilai nyeri leher mekanik sebelum pemberian program McKenzie Neck Exercise maksimal nilai 4 (nyeri sedikit berat) dan minimal nilai 3 (nyeri sedang), setelah latihan nilai nyeri turun maksimal nilai 2 (nyeri ringan) dan minimal nilai 1 (tidak nyeri).

Pada Kelompok II juga terlihat bahwa rentang nilai nyeri leher mekanik sebelum pemberian program Forward Head Posture Exercise maksimal nilai 4 (nyeri sedikit berat) dan minimal nilai 3 (nyeri sedang), setelah latihan nilai nyeri turun maksimal nilai 2 (nyeri ringan) dan minimal nilai 1 (tidak nyeri).

\section{Uji Normalitas dan Homogenitas}

Tabel 3.

Hasil uji normalitas dan homogenitas

\begin{tabular}{|c|c|c|c|c|c|c|}
\hline \multirow{3}{*}{ Kelompok } & \multicolumn{3}{|c|}{ Shapiro Wilk Test* } & \multirow{2}{*}{\multicolumn{3}{|c|}{$\frac{\text { Levene's Test }^{* *}}{p}$}} \\
\hline & \multicolumn{3}{|c|}{$p$} & & & \\
\hline & Pre & Post & Selisih & \multicolumn{3}{|c|}{ Pre Post Jelisih } \\
\hline KP I & 0,001 & 0,001 & 0,001 & \multirow{2}{*}{1,000} & \multirow{2}{*}{0,075} & \multirow{2}{*}{0,70} \\
\hline KP II & 0,001 & 0,001 & 0,008 & & & \\
\hline
\end{tabular}

Berdasarkan Tabel 3 di atas, hasil uji normalitas menunjukkan bahwa keseluruhan data pada masing-masing Kelompok sebelum dan sesudah program latihan diperoleh nilai $p$ $0,001(p<0,05)$ yang berarti data berdistribusi tidak normal. Sedangkan, pada hasil uji homogenitas sebelum diberikan program latihan didapatkan nilai $p 1,000$ dan setelah program latihan didapatkan nilai $p \quad 0,075$ $(p>0,05)$ yang menunjukkan data homogen.

\section{Uji Beda Nyeri Leher Mekanik Antar Kelompok I dan II}

Tabel 4.

Hasil Uji Beda Kedua Kelompok

Nilai Nyeri Leher Mekanik

\begin{tabular}{cccc} 
Kelompok & Pre-Post & Pre-Post & Selisih \\
\cline { 2 - 4 } Data & KP I & KP II & KP I-KP II \\
\hline \multirow{2}{*}{ Mean \pm SD } & $3,36 \pm 0,50-$ & $3,36 \pm 0,50-$ & $2,18 \pm 0,40-$ \\
& $1,18 \pm 0,40$ & $1,36 \pm 0,50$ & $2,00 \pm 0,63$ \\
$p$ & 0,002 & 0,003 & 0,44 \\
\hline
\end{tabular}

Sebagaimana terlihat pada Tabel 4, hasil penelitian ini menunjukkan bahwa terdapat 
penurunan nyeri leher yang signifikan $(p<0,05)$ baik pada Kelompok I maupun Kelompok II $(3,36 \pm 0,50-1,18 \pm 0,40$ vs. $3,36 \pm 0,50-$ $1,36 \pm 0,50)$. Hasil perbandingan penurunan nyeri menunjukkan bahwa tidak ada perbedaan yang signifikan secara statistik $(p 0,44)$ antara Kelompok I dan Kelompok II $(2,18 \pm 0,40$ vs. $2,00 \pm 0,63)$.

\section{PEMBAHASAN}

Dari hasil analisis penelitian yang dilakukan selama sepekan dengan durasi 30 menit/hari menunjukkan bahwa program McKenzie Neck Exercise dan Forward Head Posture Exercise terbukti dapat menurunkan nyeri leher mekanik pada pengguna smartphone dengan efektifitas yang sama baiknya.

Secara konseptual, nyeri leher mekanik terjadi sebagai proses nosisepsi dari sebuah stimuli kimia berupa pelepasan asam arachadonic oleh sel-sel otot yang over aktif mengalami ketegangan, stress mekanis, spasme, iritasi, dan mengakibatkan iskemik lokal, yang seterusnya memicu produksi prostaglandin, thromboxane, monohydroxy fatty acids, dan leukotrienes, mendorong progresitas pelepasan komplemen aktivator nyeri seperti histamin, serotonin, dan bradikinin. Kemudian menstimuli ujung-ujung serabut saraf bermyelin tipis tipe $\mathrm{C}$ melalui mekanisme depolarisasi (masuknya ion $\mathrm{Na}^{+}$dan keluarnya ion $\mathrm{K}^{+}$) pada membran sel, menyebabkan terjadinya potensial aksi impuls saraf $\mathrm{C}$ dengan kecepatan konduksi $0,4-1 \mathrm{~m} / \mathrm{s}^{10,15}$.

Impuls nyeri dari serabut saraf tipe $\mathrm{C}$ diteruskan melalui jalur lambat traktus paleospinothalamicus menuju dorsal horn medula spinalis, tepatnya di lamina II dan III yang dikenal dengan substansi gelatinosa (SG). Di SG saraf C melepaskan neurotransmitter seperti; asam amino eksitatoris (EAAs) glutamat dan aspartat, serta calcitonin gene related peptide (CGRP) dan substansi $\mathrm{P}$, di sinaps yang akan menimbulkan impuls saraf di cornu dorsalis ke sistem yang berada di atasnya. EAAs berperan sebagai mediator transmisi eksitasi di sistem saraf pusat (SSP). Sedangkan CGRP dan substansi $\mathrm{P}$ berperan mengaktifkan neuron spinal serta meningkatkan respon neuron spinal terhadap EAAs ${ }^{10,15}$.

Pelepasan neurotransmitter EAAs, CGRP, dan substansi $\mathrm{P}$, mengaktivasi kalsium kinase untuk memecah asam arachadonic, yang bertujuan menginaktifkan reseptor N-metil Daspartat (NMDA) yang berfungsi sebagai "gate" (pintu gerbang masuk) di SG, dengan meniadakan blokade magnesium voltage dependent dari reseptor NMDA. Menyebabkan gate terbuka, sehingga impuls nyeri menuju wide dynamic range neuron (WDRN) atau dikenal dengan sel $\mathrm{T}$ di lamina $\mathrm{V}$. Teraktivasinya WDRN menimbulkan keadaan hipereksitabilitas neuron pada dorsal horn. Efek yang timbul adalah peningkatan sensasi nyeri dengan lokalisasi jelas, yang dapat berlangsung selama beberapa menit hingga beberapa jam. Sensasi nyeri inilah yang kemudian dikirim secara ascenden ke SSP lebih tinggi via commisura alba anterior jalur anterolateral dan berakhir di thalamus, sebagian di medulla, pons, dan substansia griseria sentralis dari rectum mesensephalon, kemudian menuju ke area somatosensoris korteks serebri kontralateral, tempat dimana informasi mengenai lokasi, intensitas, kualitas nyeri untuk diterjemahkan sebagai persepsi nyeri ${ }^{10,15}$.

Pemberian program McKenzie Neck Exercise dan Forward Head Posture Exercise dengan gerakan mobilisasi dan regangan lembut pada setiap tahapannya, dapat mengaktifkan mechanoreceptor serabut saraf bermyelin tebal tipe $A \beta$ terutama ruffini (tipe II) dan intertisial (tipe IIIa) yang terletak di kulit, connective tissue, otot, tendon, dan sendi, dengan kecepatan konduksi 36-72 m/s, menuju lamina II dan III di SG melalui jalur cepat traktus neospinothalamicus pada dorsal horn medulla spinalis ${ }^{10,11}$.

Teraktivasinya serabut saraf bermyelin tebal tipe $A \beta$ ini di lamina II dan III, memblokade magnesium voltage dependen pada reseptor NMDA untuk menutup gate di SG. Tertutupnya gate di SG, menyebabkan terinhibisinya transmisi sinaptik dari serabut saraf bermyelin tipis tipe $\mathrm{C}$, yang akan menurunkan eksitabilitas sel $\mathrm{T}$ di lamina $\mathrm{V}$ dari mengirimkan impuls nyeri ke susunan saraf yang lebih tinggi ${ }^{10,11}$. 
Pada tingkat spinal dan supraspinal, juga terjadi pelepasan neutrotransmitter ensepalin yang berasal dari perikuaductal gray (PAG) dan periventricular nuclei secara descenden melalui jaras transmisi nuclei raphe magnus (NRM) untuk diteruskan ke SG di dorsal horn medulla spinalis. Opioid endogen (ensepalin) selanjutnya bekerja primer di presinaptik dan post sinaptik dengan menginaktifkan kalsium kinase dari memecah asam arachadonic, bertujuan untuk menginhibisi pelepasan neurotransmitter nyeri, seperti; histamin, serotonin, bradikinin, EAAs, CGRP, dan substansi P. Sehingga efek nyeri semakin menurun pada keadaan somatosensoris yang normal $^{10,11}$.

Secara praktis, ke dua program latihan (McKenzie Neck Exercise dan Forward Head Posture Exercise) memiliki kesamaan prinsip dari segi otot target yang diaktivasi, meliputi otot sternocleidomastoid, fleksor servikal terdalam, erector spine, retraktor skapula, group otot suboksipital, otot dada, dan otot levator skapula. Teraktivasinya sinergisitas dari otot-otot tersebut, akan menghasilkan impuls yang kuat pada muscle spindle (MS) dan golgi tendon organ (GTO). MS merupakan reseptor di otot yang menerima rangsangan langsung dari kontraksi otot, sementara GTO merupakan stretch reseptor yang terletak di dalam tendon otot dan bereaksi terhadap penguluran berlebih pada otot ${ }^{12,16,17}$.

MS dan GTO, bekerja sama untuk mengontrol dan mendeteksi seluruh ketegangan selama otot berkontraksi. MS bekerja untuk mempertahankan panjang otot secara tetap dengan memberikan umpan balik pada perubahan kontraksi, dimana MS berperan menghentikan impuls saraf yang meningkatkan ketegangan pada otot antagonis guna mencegah terjadinya penguluran berlebihan. Peristiwa ini menghasilkan relaksasi otot antagonis, atau disebut reciprocal inhibition. Sementara, impuls saraf sensoris dari GTO masuk ke bagian dorsal spinal cord dan bertemu dengan inhibitor motor neuron. Proses ini mencegah kontraksi otot agonis lebih lanjut terjadi, disertai penurunan tonus otot, menghasilkan rileksasi pada otot agonis, dikenal dengan post isometric relaxation $^{12,16,17}$.
Dengan demikian, ke dua program latihan (McKenzie Neck Exercise dan Forward Head Posture Exercise) dapat menciptakan gerak proporsi yang seimbang dengan meningkatkan perbaikan propriosepsi di otot, tendon, sendi, dan connective tissue di sekitar leher, punggung atas, dan bahu. Sehingga terjadi efek penguatan dan stabilitas pada group otot agonis dan antagonis, yang secara langsung dapat mengoreksi posisi forward head posture dan mengurangi terjadinya nyeri leher mekanik.

\section{KETERBATASAN PENELITIAN}

Ada sejumlah faktor kemungkinan dapat mempengaruhi perkembangan intensitas nyeri leher mekanik yaitu aktivitas fisik yang dilakukan oleh responden di luar jadwal penelitian, di antaranya; kurangnya kesadaran diri, kebiasaan, maupun durasi penggunaan smartphone. Hal ini bisa menjadi kelemahan penelitian, sebab ke tiga aspek tersebut belum diteliti sepenuhnya. Hal lainnya seperti melakukan pola gerakan dan teknik pelemasan pada otot, boleh jadi bentuk lain dari metode corrective neck exercise, yang tidak diamati oleh peneliti.

\section{SIMPULAN}

Program McKenzie Neck Exercise dan Forward Head Posture Exercise efektif menurunkan nyeri leher mekanik pada pengguna smartphone dengan efektivitas yang sama baiknya.

\section{DAFTAR PUSTAKA}

1. Bolash. 2017. Text Neck: Is Smartphone Use Causing Your Neck Pain? Euclid Avenue, Cleveland, Ohio.

2. Kong YS., Yu-Mi K., Je-Myung S. 2017. The effect of modified cervical exercise on smartphone users with forward head posture. Journal of Physical Therapy Science. 29(2): 328-331.

3. Coenen P., Siao HT., Erin KH., Leon MS. 2017. The Associations of Mobile Touch Screen Device Use with Musculoskeletal 
Symptoms and Exposures: A Systemic Review. Research Article of PLOS One.

4. Kerkar P. 2018. Forward Head Posture: Causes, Symptoms, Treatment, and Exercises. Pain Assist Inc. http://www.epainassist.inc. Di akses tanggal 10 Oktober 2018.

5. Hansraj KK. 2014. Assessment of Stresses in the Cervical Spine Caused by Posture and Position of the Head. Surgical Technology International $X X V$.

6. Goodarzi F., Leila R., Noureddin K., Raziyeh B. 2018. The Effects of Forward Head Posture on Neck Extensor Muscle Thickness: An Ultrasonographic Study. Journal of Manipulative and Physiological Therapeutics. Elsevier. Pages 34-41.

7. Burt HA. 2015. Effects of Faulty Posture. Proceedings of the Royal Society of Medicine. Vol. XLIII.

8. Silva AG, David P, Sharples P, Paulo VB, Jhonson M. 2013. Head posture assessment for patients with neck pain: Is it useful? International Journal of Therapy and Rehabilitation. 16(1).

9. O'Sullivan K., Sheikhoseini R., Sharhbanian S., Sayyadi P. 2018. Effectiveness of Therapeutic Exercise on Forward Head Posture: A Systematic Review and Meta-analysis. Journal of Manipulative and Physiological Therapeutics. Vol. 41. 530-39.

10. Prentice W. 2002. Therapeutic Modalities For Physical Therapists. Second Edition. The McGraw-Hill Companies, Inc.

11. Kapandji IA. 2007. The Physiology of the Joints. Volume III. $6^{\text {th }}$ ed. London: Churchill Livingstone.

12. Richa R., Kataria C., Bansal K. 2012. Comparative Effectiveness of Muscle Energy Technique and Static Stretching for the Treatment of Subacute Mechanical Neck Pain. International Journal of Health and Rehabilitation Sciences. 1(1): 16-24.

13. McKenzie R., Kubey C. 2014. 7 Steps to a Pain-Free Life:How to Rapidly Relieve Back, Neck, and Shoulder Pain. FA. Davis Company.

14. McQuilkie., Turetsky. 2018. How to Fix Forward Head Posture - 5 Exercises.
http://Backintelligence.com. Diakes tanggal 10 Januari 2019.

15. Freudenrich. 2011. How Pain Work. http//science.howstuffworks.com. Diakses tanggal 17 Juli 2019.

16. Kisner C., Colby LA. 2013. Therapeutic Exercise: Foundations and Techniques. 6th Edition. FA. Davis Company.

17. Heintz MM., Hegedus EJ. 2008. Multimodal management of mechanical neck pain using a treatment based classification system. Journal of Manual and Manipulative Therapy. 16(4):217-24. 